\title{
The Correlation of Digital Literation and STEM Integration to Improve Indonesian Students' Skills in 21st Century
}

\author{
${ }^{1}$ Eris Nurhayati, ${ }^{2}$ Dedi Riyan Rizaldi*, ${ }^{3 Z i a d a t u l ~ F a t i m a h ~}$ \\ 1,2,3University of Mataram, Natural Sciences Education Study Program, Indonesian \\ *e-mail: dedi0313@gmail.com
}

\begin{tabular}{l}
\hline \multicolumn{1}{c}{ Article Information } \\
\hline Received: 01 August 2020 \\
Revised: 07 August 2020 \\
Online: 03 September 2020 \\
\hline \multicolumn{1}{c}{ Keywords } \\
\hline 21st Century Skills, Digital Literacy, \\
Digital Competency, STEM
\end{tabular}

\begin{abstract}
Dynamic human development in the 21st Century demands students to make innovations in the world of education. Students are required to have 21st-century skills, namely creativity, critical thinking, collaboration, and communication. In contrast, teachers are required to have skills that must be mastered. The six capabilities are mastery of knowledge/content, mastery of 21st-century pedagogy, the ability of expertise in the development and achievement of students and give support, mastery of learning psychology skills; having counseling skills; and competence in using information technology and media. This article aims to discuss issues related to how to improve the ability of teachers and students to master 21st-century skills? Also, what extent is the role of digital literacy and STEM integration in improving 21st-century skills? This article using literature literacy methods sourced from international and national journals, books, and other relevant sources. Based on the study, it concluded that digital competence is not an absolute determinant of the development of 21st-century skills in students. Digital ability is a supporting factor for mastering 21st-century skills that should have been introduced and taught through schools. STEM learning with multidisciplinary mastery of science needs to be optimized in schools in Indonesia so that the expected learning objectives are in line with the demands of the 21st-century.
\end{abstract}

\section{INTRODUCTION}

In the information era, it allows each individual to develop their talents and potential through "Technology-Based Knowledge." It is the main challenge facing students today and in the future. Students must be prepared not only in terms of excellent academic achievement but also in 21st-century skills to meet these challenges. To solve the various problems faced by students, Rusdin (2017) states that they must master 21st-century skills, namely (1) creativity; (2) critical thinking; (3) collaboration; and (4) communication, as well as the equivalent of the four things, his mastery of technology.

Indonesia competes with all countries in the world in the face of the Industrial Revolution 4.0 eras. Kagermann, in his writings, Prasetyo and Sutopo (2018), the emergence of the term Industry 4.0, was officially born in Germany precisely at the Hannover Fair, which was held in 2011. The German state has a great interest in this because the industrial revolution 4.0 is one of the policy development plans called High-tech Strategy 2020. Increased growth in manufacturing digitalization is driven by several factors including

1. Increasing the level of data volume, computing power, and internet connectivity;

2. the emergence of analytical understanding, capabilities, and business intelligence; 
3. there are new forms of interaction that occur between humans and machines; and

4. Development of an increase in digital transfer infrastructure to the physical world, such as the existence of robotics and 3D printing.

The basic principle of the Industrial Revolution 4.0 is the integration of machines, workflows, and systems, by implementing networks in various chains and processes of production movement to control each other (Hamdan, 2018; and Lase, 2019). So, that indirectly, all activities carried out by humans will apply the technology system, including in the field of education. It is in line with Marlina (2019) statement that technology is one of the most important keys that will be able to improve the quality of a school, especially in the teaching and learning process with the integration of character content and technological developments.

According to Herman et al. (2016), in his writing, Sri Sugiarto stated that the era of the industrial revolution 4.0 had several principles that had to be understood and understood by all other circles of interconnection, transparent information, assistance from the industrial sector, and decentralized decisions.

1. Interconnection (connection), namely the ability of machines, devices, sensors, and people to connect and communicate with each other through the Internet of Things (IoT) and the Internet of People (IOP) followed by new technology in data science (Boavida, 2016; McKenna, 2018). In the application concept, this principle requires collaboration, security, and standards that can facilitate internet technology that can be used in all sectors and unlimited conditions of time and place.

2. Transparent information is the ability of information systems to make virtual copies of the physical world by enriching digital models with sensor data, including data analysis and information provision. With maintained security can increase the confidence of all people in using the internet (Santosa, 2019; Yusnaini and Slamet, 2019). It has become one of the factors that cause many people do not dare to use technology in every activity undertaken.

3. Assistance in the technology sector includes providing data security and speed in assisting human work in the form of visual and physical abilities.

4. Decentralized decisions are the ability of virtual physical systems to make their own decisions and carry out tasks as effectively as possible. Effectiveness and time efficiency are expected to be able to improve the performance and outcomes resulting from a process that has been carried out. The generation of Innovation in science and technology (Science \& Technology) has become an essential key of a developing country to be fully developed or equal to developed countries at the beginning of the 21st Century (Byhee, 2010).

Information and Communication Technology (ITC) is the basis for developing innovations. However, it must be made an association and integration with subjects learned by students in school. In real life, the problems faced are not compartmentalized in certain subjects. Students must learn to solve a problem not only from one subject's point of view, therefore what is more appropriate is to choose a theme to be extracted from various multidisciplinary sciences and be associated with technology, which is now known as STEM (Science, Technology, Engineering, and Mathematics). STEM is one of the education systems that has been carried out in various countries in the world (Pujiati, 2019). It is because this system can produce human resources with diverse abilities, not focused on just one skill (according to the demands of 21st-century skills). Therefore, various research and development of STEM education have become an exciting theme in various educational journals and seminars.

On the other hand, the term STEM is a new thing in Indonesia in recent years. Various study groups in Indonesia have started trying to apply STEM education to develop student knowledge and skills not only related to cognitive aspects but also related to affective and psychomotor aspects (Sartika, 2019). It is because STEM education provides opportunities for students to actively participate in the learning process by collaborating, being disciplined, communicative, and integrating various experiences in their lives. These three critical points are expected to be achieved by integrating STEM with 21st-century skills, especially those related to digital literacy.

Based on the problems discussed earlier, it is necessary to discuss this article to find out which articles about 21st-century skills are needed with specific digital competencies in the learning system in Indonesia. Is there an influence between digital skills in developing 21st-century students' skills? By developing STEM, will it improve the 21st-century skills needed by students? 


\section{METHODS}

The research method used in this study is library research, which is done through the collection of articles or scientific papers relating to digital skills, 21st-century skills, and that connects the two. This research is qualitative, by observing phenomena that occur in Indonesia, formulating problems that occur, and then related to the literature obtained. Data collection techniques are carried out by triformulation (combined) in the form of literature review by collecting data, especially verbal data through books, articles, notes, and various other scientific literature. The data collected is then analyzed inductively to produce grounded theory, which is a theory that emerges from data not from hypotheses (Setyosari, 2013). Writing steps in preparing this article are

1. choosing a problem;

2. a preliminary study;

3. formulating the problem;

4. formulating objectives;

5. conducting a study;

6. making a discussion;

7. formulating a conclusion drawn from the results of the analysis and recommendations for other writers.

\section{RESULTS \\ Technology in Human Life}

Along with the times, technology can not be separated from humans. Technology is needed to help facilitate social work. Also, in the world of work, 21st-century skills such as evaluating information, solving problems, exchanging information, or developing ideas in a digital context are considered necessary. This development requires the ability of an individual in the mastery of these skills. 21st Century skills and digital proficiency are both considered essential for making a product and process innovations. McNicol (2015), states that the impact of the growth of globalization and public knowledge has argued that 21st-century skills are crucial for success in the workplace and Information Communication and Technology (ITC) is central to their development. In line with this, Claro et al. (2012) define 21st-century digital skills as 1) mastery of ICT applications to solve cognitive tasks at work; 2) skills that are not driven by technology because they do not refer to the use of specific software programs; 3) skills that support high-level thought processes; and 4) skills related to cognitive processes that support continuous learning.

Technology develops along with cultural development. Technological development is motivated by a dynamic human nature. Technology is the most crucial part nowadays that cannot be separated from social activities. The technology was created to meet the growing human desire and want to be fast. The beginning of the goal of creating technology is to help and provide convenience in various aspects of human life, both to facilitate work, activities outside of work, and to communicate (Beret, 2014). With the presence of technology, human productivity has increased. Technology can shape individuals in terms of ways of thinking and behaving in society. Technological advances in the field of communication have both positive and negative sides. On the positive side, people are more efficient at sending messages, and it is easier to find the latest sources of information and more practical to form a community (Ferguson, 2015). However, the negative side of technological advances is that technology makes it easy for people to communicate with those whos are furthest away but keep communication away from those closest to them.

\section{Technology Skills}

Various terms are used to link human activities with ITC. The spread of digital technology, words such as I.T. (Information Technology) and ITC (Information and Computer Technology), has become prevalent (Bawden, 2008). Technology plays a dominant role in determining which skills are considered essential. In the current era and the future requires everyone to have expertise in using technology. It is because it can be used as a fundamental skill in improving 21st-century skills. The success or failure of a person's survival in the future can be seen from how much ability the person has in using technology. Technology skills are abilities that a person has in conducting online-based communication or using various electronic devices. These concepts mainly show a basic set of skills in using computers or 
Internet technology; for example, shutting down a computer, opening folders, and saving files. They do not go too far to explain the skills an individual must have to exploit the full potential of ITC. However, their technical skills are the driving force for meeting the needs of 21st Century skills while acquiring 21st-century digital skills.

\section{1st Century Digital Skills}

Digital competence is a critical concept in discussing the types of skills and understanding that people must-have. Digital competencies include information management, collaboration, communication and sharing, content and knowledge creation, ethics and responsibility, evaluation and problem solving, and technical operations (Ferrari, 2012). The Partnership has created the thinking framework of 21st-century education for 21st Century Skills (P21), a group that focuses on learning 21st Century skills. P21 integrates academic knowledge, critical thinking, and social skills in learning to help students master skills multidimensional requirements in the 21st Century (Alismail \& McGuire, 2015). Other groups and organizations have proposed similar frameworks.

The Assessment and Teaching of 21st Century Skills (ATC21S), uses a group of experts to define the keys to 21st-century skills (Byhee, 2010). 21st-century skills are categorized as 1) ways of thinking (creativity and innovation, critical thinking, problem-solving, and decision-making), 2) ways of working (communication, collaboration, and teamwork), 3) tools for working (information literacy and information communication technology) and 4) life in the world (life and career, personal and social responsibilities). The main focus is on teaching and learning practices ensuring the mastery of students in the classroom of 21st-century skills as provisions when he is outside the school or in real life (Leahy \& Dolan, 2010).

Indicators of 21st-century skills generally consist of 3 groups, (1) life and career skills, (2) learning and innovation skills, and (3) Information media and technology skills. The three skill groups are summarized in a scheme called the Rainbow of 21st Century knowledge skills (21st Century rainbow knowledge-skills)(Bellanca and Brandt, 2010). The program was adopted by the nonprofit organization P21, which developed the 21st Century educational framework throughout the world through the website www.p21.org based in the state of Tucson, USA. The concept of 21st-century skills and 3 R core subjects is described in the following figure.

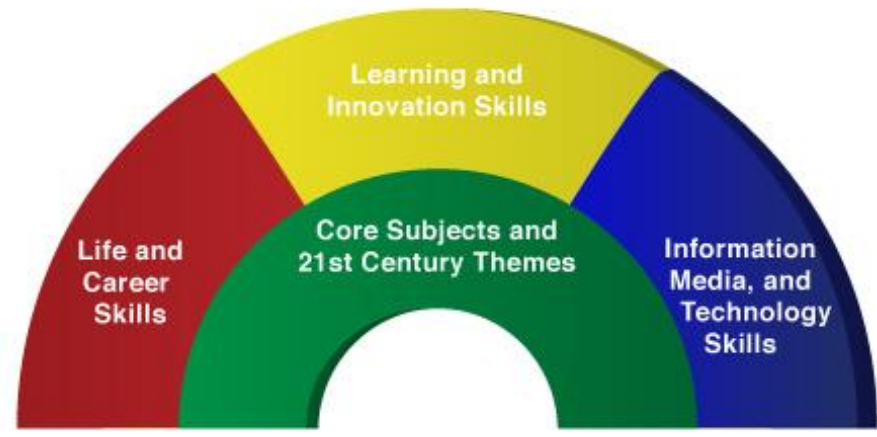

Figure 1. Rainbow Knowledge Skills of the 21st Century Sources: Bellanca and Brandt, 2010.

The scheme developed by P21 is made clear with the addition of core subject 3R. In the context of education, $3 \mathrm{R}$ is an abbreviation of reading, writing, and arithmetic, a sharp "R" pronunciation is taken from each word. From the subject of reading and writing, modern educational ideas emerge, namely literacy, which is used as learning to understand concepts through the medium of words. The issue of arithmetic arises against advanced education related to numbers, which means that they can recognize names through mathematics. In school, there is no single term that is relevant to literacy and numeracy that can express the ability to make something (writing).

The $3 \mathrm{R}$, adapted from the 18th and 19th centuries, is equivalent to the literacy, numeracy, and ITC functional skills found in today's modern education system. Furthermore, to clarify the function of 3 R core subjects in the context of 21st-century skills, $3 \mathrm{R}$ is translated into life and career skills; learning and innovation skills; and information media and technology skills. Life and career skills include: 
1. Flexibility and Adaptability; can adapt to change and be flexible in learning and doing activities in groups;

2. Initiative and Self-direction; can manage goals and time, work independently and become students who can handle themselves;

3. Social and Cross-cultural Interaction; can interact and work effectively with diverse groups;

4. Productivity and Accountability; can manage the project and produce products; and

5. Leadership and responsibility; can lead his friends and be accountable to the broader community.

Learning and innovation skills include:

1. Critical Thinking and Problem Solving; reasoned, reflective thinking that focuses on determining what needs to be believed and done. The ability to think critically usually begins with the ability to criticize various phenomena that occur around them, then judge from the point of view they use. Then he positioned himself, from an awkward situation to a situation that favored him,

2. Communication and collaboration; where communication is an ability which includes the activities of using the skills of writing, listening, studying, interpreting, and evaluating an idea, symbol, term, and other information observed through the process of listening, presenting and discussing so that it can be applied in a team collaboration process, and

3. Creativity and Innovation; is the ability to produce something new. Student creativity needs to be trained and developed every day to deliver breakthroughs or changes to help themselves in addressing a problem or for others. Creativity equips a student who has the competitiveness and provides some opportunities for him to be able to fulfill all his life needs.

Information media and technology skills include:

1. Information Literacy, where a person can access information effectively (information sources) and efficiently (time), evaluating information that will be used critically and competently, manage information accurately and effectively to solve problems;

2. Media Literacy; where someone can choose and develop media used to communicate; and

3. Information and Communication Technology Literacy; is able where someone can analyze information media and creating appropriate media for communication.

\section{DISCUSSIONS}

\section{Relationship between Digital Skills and 21st Century Skills}

21st-century skills and digital competence are both concepts that emphasize a broad spectrum of skills. Beyond skills, knowledge, and attitudes are seen as essential things that develop in society. The list of skills mentioned is comprehensive, but the two concepts do not integrate digital aspects. Many categorizations of 21st-century skills and conceptualizations are given, but only a few frameworks are available to provide operational components. Also, if operationalization is provided, the focus is often on one particular skill. The main difference between digital skills or digital literacy is that these concepts integrate 21st-century digital skills. Although the skills mentioned tend to lead to knowledge, they do not cover a broad spectrum of 21st-century skills. However, the skills mentioned are more thoroughly measured than with 21st-century skills or digital competence. Overall, the focus is on skills related to knowledge or content. Besides, research tends to focus on citizens or students rather than the skills needed for the workforce.

21st-century skills and digital skills are both considered significant, but combinations have not been formed enough. For the dimensions of the 21st-century digital skills concept, it has been defined in several articles. The definition emphasizes the conceptualization of skills and operational components. Based on the results, a distinction is made between core skills and contextual skills. Core skills are the basis for performing tasks that are required in a variety of jobs. Contextual skills are skills that are needed to take advantage of core skills and, therefore, must be connected to these core skills.

Based on a reference study conducted by Van et al. (2017) based on the characteristics of the 75 articles included, the results show that 21st-century skills have a broader impact than digital skills. Furthermore, outside of skills, knowledge, and attitudes are seen as necessary for developing in society. Besides, 21st-century skills do not have to be supported by ITC, while digital or literacy skills do provide such integration. Also, many 21 st-century skill categorizations are provided, but only a few frameworks are available to provide operational components. The digital skills mentioned can be more scalable than 21st-century skills. After evaluating the article, there are seven core skills: technical, information 
management, communication, collaboration, creativity, critical thinking and problem solving, and five contextual skills: ethical awareness, cultural awareness, flexibility, self-direction, and a lifelong learner. In the global knowledge economy, these skills largely determine an organization's competitiveness and capacity to drive Innovation. Given the rapid rate of change and the influence of technology, the workforce needs to develop 21st-century digital skills to keep up with the dynamic development of society.

\section{STEM (Science, Technology, Engineering, and Mathematics)}

STEM education is one of the multidisciplinary sciences that integrates knowledge and skills from four fields: science, technology, engineering, and mathematics (Morrison et al., 2009). The term STEM was first launched by the United States National Science Foundation around the 2000s as a theme of an education reform movement in all four fields and first known as SMET, which was later changed to STEM. The scope of each area includes:

1. Science is one part of science that studies various facts related to phenomena that occur in the universe;

2. technology is an innovation developed to meet human needs and desires;

3. engineering is a profession that involves science, and mathematic; and

4. mathematics is a branch of a scientific discipline that studies various patterns or relationships.

The purpose of developing and using the STEM are:

1. Growing STEM literate communities;

2. produce a workforce in STEM fields; and

3. increasing the competitiveness of people globally (Farwati et al., 2018; Suwardi, 2020).

In the current context, STEM aims to prepare students to face challenges that arise in our world today, such as lack of energy and environmental and health problems (Byhee, 2010). Students who are equipped with STEM knowledge can identify, apply, and integrate their concepts to understand complex issues and produce innovative solutions to solve those problems (Chew et al., 2013). According to Pujiati (2019) that implementing STEM learning can improve students' scientific and digital literacy skills, so that it will have a direct impact on the expected final ability in education. Also, in various similar studies that STEM can improve problem-solving skills, critical thinking skills, and creativity because of the integration between knowledge and technological advances according to the demands of 21st-century skills (Dewi et al., 2018; Ismayani, 2016; Wahyuaji and Suparman, 2019).

The results achieved by students in TIMSS (Trends in International Mathematics and Science Study) and the Program for International Student Assessment (PISA) recorded Indonesia in the top 10 in the world rankings, even below Malaysia (IEA, 2012). It is due to the low ability of student literacy and to the lack of efficiency in the Teaching and \& Learning method and our current education system, which does not emphasize higher-order thinking skills (HOTS). Then there need to be steps that encourage teachers to take initiatives in self-development, increase knowledge and skills, and apply new teaching and learning practices addressing the needs of the 21st Century. Education must be delivered in an integrated manner with student learning activities.

The teacher needs to use various techniques such as brainstorming, role plays, games, and student-centered learning activities that are appropriate to the content and skills planned to be achieved during the learning session. At this point, creativity skills become an essential element that empowers the teacher's ability to use as many techniques as possible to generate ideas, develop, and communicate new ideas effectively. Six creativity skills that must be possessed and mastered by a teacher are:

1. Mastery of knowledge/subject/content;

2. mastery of 21st-century pedagogy;

3. mastery of skills in tracking student progress and achievement and providing support;

4. mastery of learning psychology skills;

5. have counseling skills; and

6. competent in using information technology and media.

Walser and Turiman state that the integration of technology into the realm of learning for students aiming to master 21st-century skills such as information skills, collaboration, and self-access learning (Walser, 2008; Turiman et al., 2012). Wati \& Kamila (2019), stated that the success of meaningful learning at this time in addition to involving students but also the need for integration of learning with 
technology owned by students. With this integration process, students are expected to be unable to use various electronic devices in their daily activities wisely.

\section{CONCLUSION}

Based on the study of articles and references, it can be concluded that digital competence is not a determinant of the development of 21st-century skills. Despite its role, it cannot be eliminated. Along with dynamic human development, digital competencies accompany students' mastery of 21st-century skills. Teachers, as facilitators, are required to improve pedagogic skills and knowledge of scientific content, including integrating technology into the realm of learning for students to master 21st- century skills such as information skills, collaboration, and learning. The integration the multidisciplinary science was made acquired in the form of STEM learning. It is supported by many studies that explain that the application of STEM education integrated with digital literacy skills can develop students' thinking power and logic in various fields of knowledge; this is following the objectives contained in the Indonesian education curriculum.

It is expected that further in-depth research can be carried out in each school given the conditions between one school are different from other schools, the extent of the influence of digital literacy in the development of 21st-century skills, and how to optimize STEM learning so that it can be applied in each school.

\section{REFERENCES}

Alismail, H. A., \& McGuire, P. (2015). 21st century standards and curriculum: Current research and practice. Journal of Education and Practice, 6(6), 150-154.

Bawden, D. (2008). Origins and concepts of digital Literacy. In C. Lankshear, \& M. Knobel (Eds.), Digital literacies: Concepts, policies, and practices (pp. 17e32). New-York: Peter Lang.

Bellanca, J., dan Brandt, R. (2010). 21 ${ }^{\text {st }}$ Century Skills: Rethinking How Students Learn. USA: Solution Tree Press.

Byhee, B. (2010). Advancing STEM Education: A 2020 Vision. Technology and engineering teacher, 70(1), 30-35.

Boavida, F., Kliem, A., Renner, T., Riekki, J., Jouvray, C., Jacobi, M., ... \& Triviño, A. (2016). People-centric internet of things-challenges, approach, and enabling technologies. In Intelligent Distributed Computing IX (pp. 463-474). Springer, Cham. DOI: 10.1007/978-3-319-250175_44.

Chew, C.M., Idris, N., Leong, K. E. \& Daud, M.F.(2013). Secondary School Assessment Practices in Science, Technology, and Mathematics (STEM) Related Subjects. Journal of Mathematics Education, 6(2):58-69.

Claro, M., Preiss, D. D., San MartíN, E., Jara, I., Hinostroza, J. E., Valenzuela, S., ... \& Nussbaum, M. (2012). Assessment of 21st century ICT skills in Chile: Test design and results from high school level students. Computers \& Education, 59(3), 1042-1053. DOI: 10.1016/j.compedu.2012. 04.004 .

Dewi, M., Kaniawati, I., \& Suwarma, I. R. (2018). Penerapan pembelajaran fisika menggunakan pendekatan STEM untuk meningkatkan kemampuan memecahkan masalah siswa pada materi listrik dinamis. In Quantum: Seminar Nasional Fisika, dan Pendidikan Fisika (pp. 381-385).

Farwati, R., Permanasari, A., Firman, H., \& Suhery, T. (2018). Integrasi Problem Based Learning dalam STEM education berorientasi pada aktualisasi literasi lingkungan dan kreativitas. In Seminar Nasional Pendidikan IPA (Vol. 1, No. 1, pp. 198-206).

Ferguson, R.B. (2015). Multimodal literacy as a form of communication. Bachelor Thesis.Sweden: Dalarna University. 
Ferrari, A. (2012). Digital competence in practice: An analysis of frameworks. Seville: Joint Research Centre, Institute for Prospective Technological Studies. DOI: 10.2791/82116.

Hamdan, H. (2018). Industri 4.0: Pengaruh Revolusi Industri Pada Kewirausahaan Demi Kemandirian Ekonomi. Jurnal Nusantara Aplikasi Manajemen Bisnis, 3(2), 1-8. DOI: 10.29407/ nusamba.v3i2.12142.

Ismayani, A. (2016). Pengaruh penerapan STEM project-based learning terhadap kreativitas matematis siswa SMK. Indonesian Digital Journal of Mathematics and Education, 3(4), 264-272.

Lase, D. (2019). Pendidikan di Era Revolusi Industri 4.0. SUNDERMANN: Jurnal Ilmiah Teologi, Pendidikan, Sains, Humaniora dan Kebudayaan, 1(1), 28-43. DOI: 10.36588/sundermann .v1i1.18.

Leahy, D., \& Dolan, D. (2010). Digital Literacy: A vital competence for 2010?. In IFIP International Conference on Key Competencies in the Knowledge Society (pp. 210-221). Springer, Berlin, Heidelberg. DOI: 10.1007/978-3-642-15378-5_21.

McKenna, H. P. (2018). Creativity and ambient urbanizing at the intersection of the Internet of Things and People in smart cities. In International Conference on Universal Access in Human-Computer Interaction (pp. 295-307). Springer, Cham. DOI: 10.1007/978-3-319-92052-8_23.

McNicol, S. (2015). Modeling information literacy for classrooms of the future. Journal of librarianship and information science, 47(4), 303-313. DOI: 10.1177/0961000614526612.

Morrison, J., Bartlett, R., \& Raymond, V. (2009). STEM as a curriculum. Education Week, 23(19.0).

Prasetyo, H dan Sutopo, W. (2018). Industri 4.0: Telaah Klasifikasi Aspek dan Arah Perkembangan Riset. Jurnal Teknik Industri, 13(1), 17-18. DOI: 10.14710/jati.13.1.17-26.

Pujiati, A. (2019). Peningkatan Literasi Sains dengan Pembelajaran STEM Di Era Revolusi Industri 4.0. Diskusi Panel Nasional Pendidikan Matematika, 5(1).

Rusdin, NM. (2017). Teacher's Readiness in Implementing 21 ${ }^{\text {st }}$ Century Learning. Universitas Sultan Idris Malaysia: Faculty of Human Development.

Santosa, I. (2019). Pengaruh Revolusi Industri Ke-Empat (Industri 4.0) terhadap Pendidikan Tinggi berbasis Kreatifitas. In Sandyakala: Prosiding Seminar Nasional Seni, Kriya, dan Desain. (Vol. 1, pp. 1-9).

Sartika, D. (2019). Pentingnya Pendidikan Berbasis STEM dalam Kurikulum 2013. JISIP (Jurnal Ilmu Sosial dan Pendidikan), 3(3). DOI: 10.36312/jisip.v3i3.797.

Setyosari, P. (2013). Metode Penelitian Pendidikan \& Pengembangan. Jakarta: Prenadamedia Group.

Turiman, P., Omar, J., Daud, A. M., \& Osman, K. (2012). Fostering the 21st-century skills through scientific literacy and science process skills. Procedia-Social and Behavioral Sciences, 59, 110-116. DOI: $10.1016 /$ j.sbspro.2012.09.253.

Wahyuaji, N. R., \& Suparman, S. (2019). Deskripsi Kebutuhan Media Pembelajaran E-learning Berpendekatan STEM Untuk Mengembangkan kemampuan Berpikir Kritis dan Kreatif Siswa SMA Kelas XI. In Seminar Nasional Pendidikan Matematika Ahmad Dahlan (Vol. 6).

Walser, N. (2008). Teaching 21st-century skills. Harvard Education Letter, 24(5).

Wati, I., \& Kamila, I. (2019). Pentingnya guru professional dalam mendidik siswa milenial untuk menghadapi revolusi 4.0. In Prosiding Seminar Nasional Program Pascasarjana Universitas PGRI Palembang (Vol. 12, No. 01).

Yusnaini, Y., \& Slamet, S. (2019). Era Revolusi Industri 4.0: Tantangan Dan peluang Dalam Upaya Meningkatkan Literasi Pendidikan. In Prosiding Seminar Nasional Program Pascasarjana Universitas PGRI Palembang (Vol. 12, No. 01). 